\title{
Morphology and relationships of the enigmatic stenothecoid pan-brachiopod Stenothecoides — new data from the middle Cambrian Burgess Shale Formation
}

\author{
Paul A. Johnston and Michael Streng \\ Acta Palaeontologica Polonica 66 (4), 2021: 723-751 doi:https://doi.org/10.4202/app.00928.2021
}

Bulk sampling of middle Cambrian carbonate units in the lower Burgess Shale Formation (Wuliuan) and the upper Wheeler Formation (Drumian) in Utah have yielded abundant silicified stenothecoids. Previously unreported from the Burgess Shale, stenothecoids discovered include at least two species: Stenothecoides cf. elongata and Stenothecoides rasettii sp. nov. The Utah material is assigned to Stenothecoides elongata. The new stenothecoid material confirms some earlier observations including a set of interior grooves and ridges forming nested chevrons across the midline and a finer set disposed around the interior shell margin. The chevroned grooves are interpreted here as mantle canals and the peripheral furrows as setal grooves. A prominent boss occurs at the valve apex in both valves. An apparent socket receiving the boss in the opposite valve described in earlier studies we show to be an artefact of preservation. Consequently, the bosses were juxtaposed when the valves were conjoined and so must have had some function other than valve articulation. Most extraordinary in Stenothecoides is an embayment at the shell apex, which likely represents a rudimentary pedicle foramen. This and other features including apparent articulate brachiopod-like calcitic fibrous shell microstructure replicated in silica, indicate phylogenetic propinquity of the Stenothecoida is with the Brachiopoda, not the Mollusca. However, phylogenetic proximity of the Stenothecoida relative to any of the brachiopod crown groups is unclear. Stenothecoids may represent a pan-brachiopod stem group derived from organocalcitic, multisclerite, eccentrothecimorph tommotiids via sclerite reduction to two opposing mitral sclerites. Discovery of stenothecoids in carbonate debris aprons in the Burgess Shale suggests transport of shelly biota downslope from the adjacent platform. However, their absence in siliciclastic units of the Burgess Shale preserving both shelly and soft-bodied biota indicates these units lack significant input of transported elements from the adjacent platform

Key words: Stenothecoida, Brachiopoda, Mollusca, Cambrian, Burgess Shale Formation. 
Streng [michael.streng@geo.uu.se], Department of Earth Sciences, Palaeobiology, Uppsala University, Villavägen 16, SE-75236, Uppsala, Sweden.

This is an open-access article distributed under the terms of the Creative Commons

Attribution License (for details please see creativecommons.org), which permits unrestricted use, distribution, and reproduction in any medium, provided the original author and source are credited.

Foris Full text $(4,214.5 \mathrm{kB})$ 